
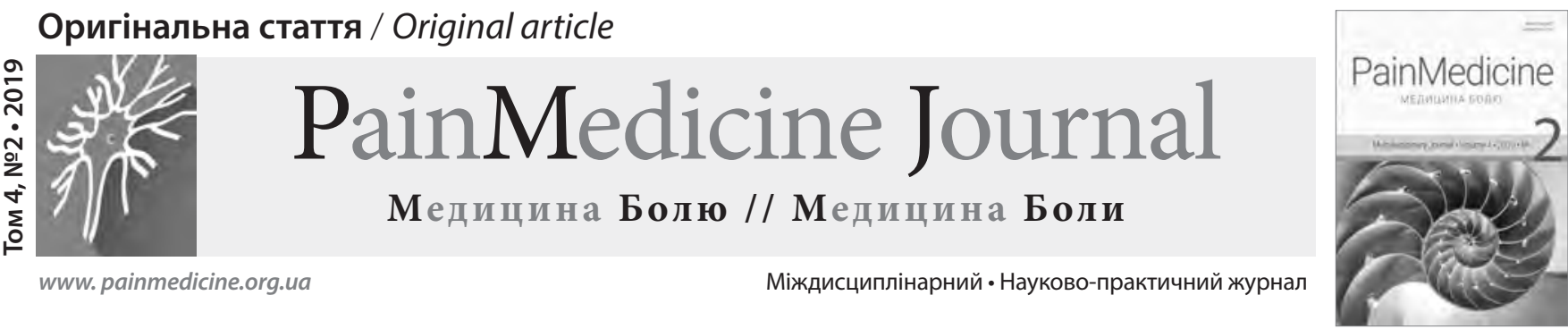

DOI: 10.31636/pmjua.v4i2.3

\title{
The Comparison of Neutropenia and Peripheral Neuropathy Condition as an Impact of 3-hours and 24-hour Paclitaxel Infusion of Paclitaxel-Carboplatin Chemotherapy on Ovarian Cancer Patients
}

\author{
Primandono Perbowo, Brahmana Askandar, Sunjoto, Ratna D Soebadi, Ahcmad Bashori \\ Gynaecologic Oncology Division, Dept. Obstetrics and Gynaecology Airlangga University, dr. Soetomo Surabaya Public \\ Hospital, Indonesia
}

\begin{abstract}
This study is aimed to compare the difference of neutropenia with peripheral neuropathy condition, after administration of 3 hours and 24 hours Paclitaxel infusion in adjuvant therapy with Paclitaxel-Carboplatin toward patient with ovarian carcinoma. The method that used was experimental research with samples randomized after consecutively recruited based on inclusive criteria. Before and every after chemotherapy, NCS was performed and differential count laboratories' test and then analysed with T-test and Chi-square test. The result showed that from three times administration of 3 hours Paclitaxel-Carboplatin infusion group, the neutropenia condition after first up to third chemotherapy was 20\%,30\%,30\%, and the peripheral neuropathy condition was $30 \%, 60 \%, 50 \%$ respectively. Meanwhile, in 24 hours Paclitaxel-Carboplatin infusion group, the incident of neutropenia after first up to third chemotherapy was $40 \%, 50 \%, 40 \%$, and the incident of peripheral neuropathy was $20 \%, 20 \%$, 20\% respectively. The statistic result was $p>0.05$. Hence, there was no significant difference in neutropenia and peripheral neuropathy incident on two study group.
\end{abstract}

Key words: Neutropenia, Peripheral Neuropathy, Paclitaxel, Carboplatin, Ovarian Carcinoma, Neuro Conduction Study.

\section{Introduction}

Among 15 types of cancers existing in the world, three of them are gynaecologic cancers including cervical cancer, ovarian cancer, and womb cancer. Ovarian cancer is also considered as the $4^{\text {th }}$ mortality cause after lung, breast, and colon cancers $[1,2,3]$.

The problem of ovarian cancer in developing countries is considered to be of high prevalence. Some cases which are discovered on the advanced stadium will cause the increase of morbidity and mortality of patients [4]. Hence, it is necessary to obtain optimal therapy toward cancers which are determined by its stadium, differentiation level, fertility, and general condition of the patients.

In this case, the neoadjuvant chemotherapy (performed before the surgery) aims to repress the growth of tumour and reduce the attachment with the surrounding 
tissues, therefore it will ease the surgery techniques and if it is possible, surgical staging will be obtained. Patients who suffer from high risk groups' ovarian cancer (stadium 1 with differentiation degree 3 , stadium $1 \mathrm{C}$, stadium 2, and clear cell tumor) will be given chemotherapy $[5,3,6]$.

The controversy in choosing chemotherapy regiment, time duration variations and the amount of dosage has not found the valid formula yet, in which it aims to get the effective results as well as minimum side effect, and thus will lead to improving of life quality $[7,8]$.

Paclitaxel is defined as medicine that has anti-cancer effect since 1960s. The combination Paclitaxel-Carboplatin is often used due to tolerated side effect than $\mathrm{Pa}$ clitaxel-Cisplatin, although there is no difference in therapy response. The Paclitaxel original schedule that agreed by experts is along 24 hours. However, there are a lot of clinical experiences which report that 24-hour infusion has several weaknesses. The weaknesses significantly cause myelosupression side effect such as neutropenia, the patients' level of comfort is neglected due to the duration of infusion that will increase the risk of nosocomial infections without setting aside the amount of dosage and combination with the platinum-based drugs, as well as it takes much costs to stay in hospital. This condition made some experts provide variation infusion start from 1 hour, 3 hours, 6 hours, 24 hours, and 96 hours in each educational and research development $[9,10$, $11,12]$.

It is mentioned in literature and studies that the differentiations of dosage are $135 \mathrm{mg} / \mathrm{m}^{2}$ for 24-hour infusion and $175 \mathrm{mg} / \mathrm{m}^{2}$ for 3-hour infusion - an internationally agreed standard (FIGO). Among the groups of 3 hours and 24 hours, it is known that there are no significant differentiation in progression-free survival, disease-free survival, and survival rate.

Some studies which evaluated side effects of 3-hour and 24-hour infusion obtained different results. The side effects were hypersensitivity, nausea and vomiting, nephrotoxicity, hepatotoxicity, peripheral neuropathy and neutropenia. Some studies have stated differently regarding on the phenomenon of high and low side effect; some of them stated no significant differences yet. Therefore, further research is required to identify the side effects of Paclitaxel-Carboplatin infusion including dosage, interval and duration that aimed to enhance knowledge about absorption, distribution, metabolism, elimination, medicine response's profile and its effectiveness $[13,14$, $15,16]$.

Heretofore, there was no study evaluating side effects of duration differentiation in chemotherapy infusion in Indonesia. Since, the research is obtained in the dr. Soetomo Public Hospital where 5-6 patients among huge amount of patients can endure chemotherapy a day. For the consideration of time efficiency, this study conducted 3 -hour Paclitaxel infusion. Thus, a researcher would like to compare 3-hour and 24-hour Paclitaxel-Carboplatin infusion in relation with neutropenia and peripheral neuropathy condition in Indonesian society.

\section{Method}

\section{Research Design}

This study was an experimental research illustrated by graphics below:

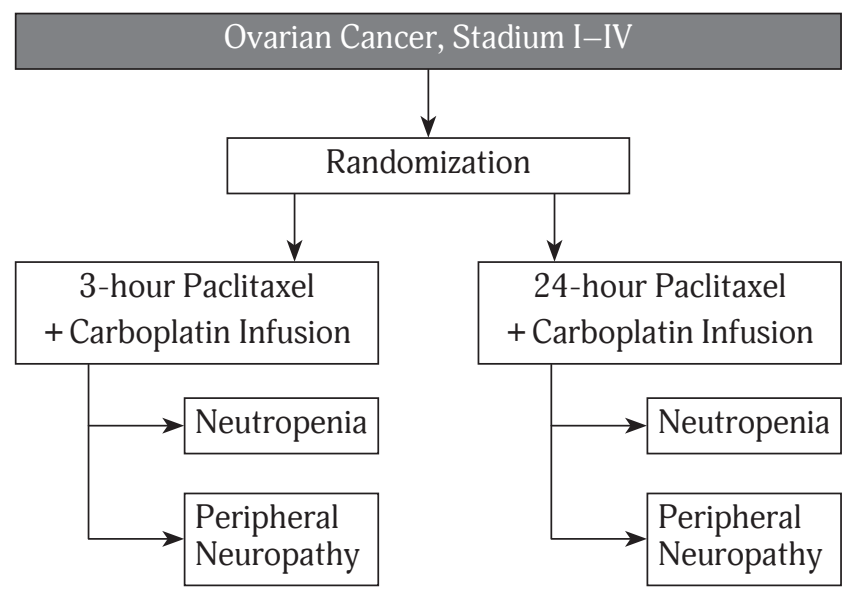

This study was conducted in Obstetrician Research Centre, Medical Rehabilitation Department, and Pathology clinic of dr. Soetomo Public Hospital of Surabaya. The population of this study was stadium I-IV ovarian cancer patients. Some of the samples had inclusion and exclusion characteristics. Moreover, in sampling technique, consecutive sampling was used. Samples were randomised by double blind to divide them into 3 -hour and 24 -hour Paclitaxel-Carboplatin infusions.

The sample amount used in this study was based on the following formula:

$$
\mathrm{n} 1=\mathrm{n} 2=\frac{(\mathrm{Z} 1 / 2 \alpha+\mathrm{Z} \beta)^{2} \mathrm{p} \times \mathrm{q}}{(\mathrm{p} 1-\mathrm{p} 2)^{2}}
$$

Significance level $\rightarrow \alpha=0,05 \rightarrow \mathrm{Z} 1 / 2 \alpha=1,96$

Test power $(1-\beta) \quad \rightarrow \beta=0,20 \rightarrow Z \beta=0,842$

$\mathrm{n} 1$ = sample group of 3-hour infusion

n2 = sample group of 24-hour infusion

$\mathrm{z}=$ default value in normal distribution

$$
q=1-p=1-0,373=0,627
$$

$\mathrm{p}=$ neutropenia chemotherapy in Paclitaxel-Carboplatin proportion 


$$
\begin{aligned}
& \mathrm{n} 1=\mathrm{n} 2=\frac{(1.96+0.84)^{2} \times 0.373 \times 0.627}{(0.315)^{2}}=9.8 \sim 10 \\
& \mathrm{n} 1=\mathrm{n} 2=10 \text { samples }
\end{aligned}
$$

The minimum sample in this study was 10 patients in each group and the total amount -20 samples.

\section{Sample Criteria}

1. Inclusion Criteria

- Patients with ovarian cancer, stadium I-IV (based on FIGO) whether endured optimal or suboptimal surgical debulking of tumours.

- Fulfilled chemotherapy requirements:
- Haematology normal ranges: $\mathrm{Hb}>10 \mathrm{~g} \%$, leukocytes $>3.0 \times 10^{3} / \mu \mathrm{L}$ or $<12.0 \times 10^{3} / \mu \mathrm{L}$, platelet $>100000$.

- Kidney and liver normal functioning.

- Consent to participate in this study by signing informed consent.

2. Exclusion Criteria:

- Previous chemotherapy.

- Suffering from other peripheral neuropathy disease (diabetes mellitus).

3. Drop Out Criteria:

- Patient death.

- Not regular treatment.

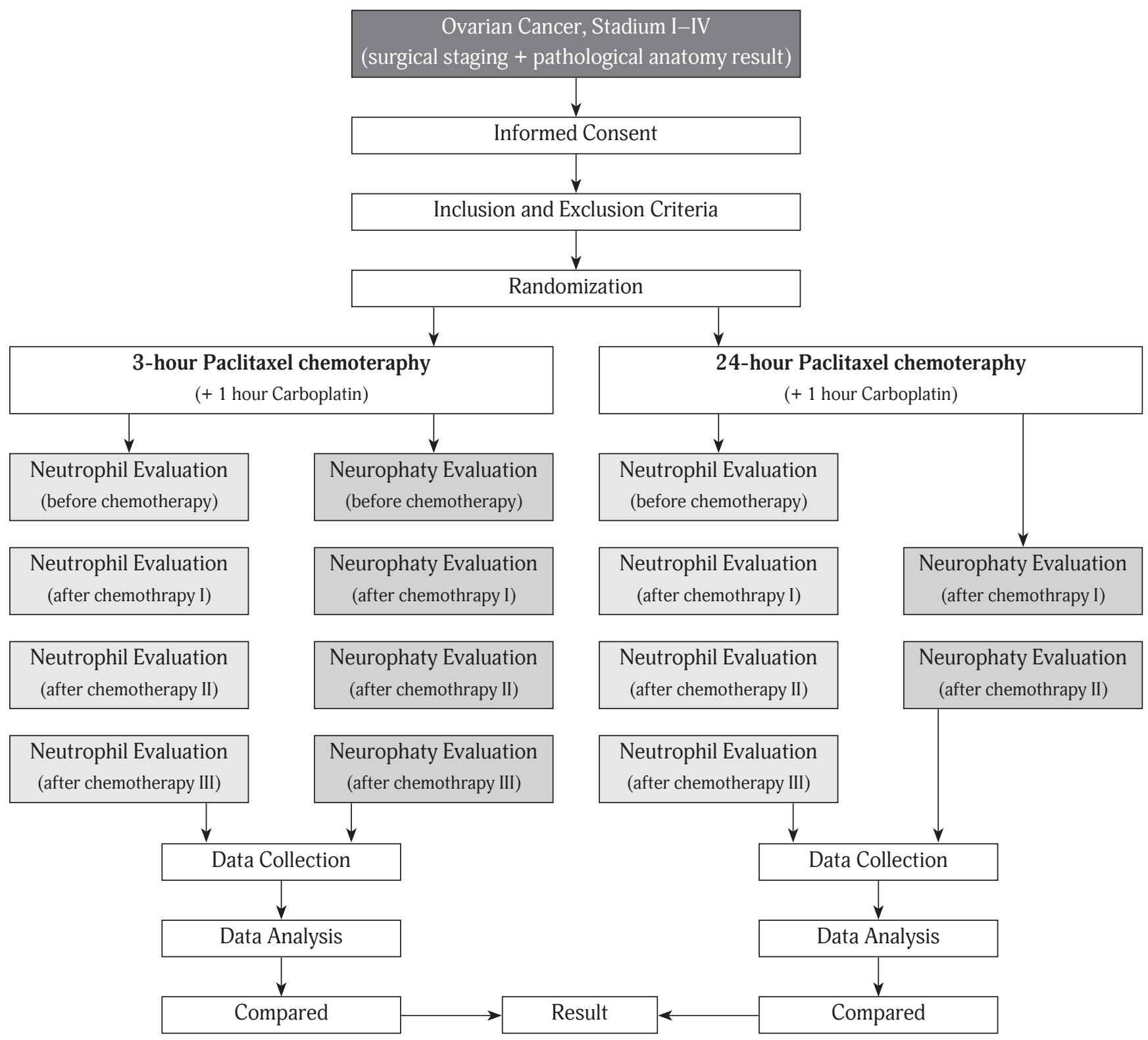




\section{Research Flowchart}

\section{Results}

The research was conducted from December 2008 up to May 2009 in the dr. Soetomo Public Hospital, Surabaya. Along the period of research, 20 samples were included into the study. It also involved 10 groups of patients of 3-hour Paclitaxel infusion and 10 groups of patients of 24-hour Paclitaxel infusion.

Each of research subject was checked for peripheral neuropathy in the Medical Rehabilitation Laboratory as well as for neutropenia in the Clinical Pathology Laboratory before the chemotherapy was obtained and after the first, second, and third chemotherapy.

This study used significant level 0.05 (5\%), so that if the ballistic testing were $p \leq 0.05$ then it can be signifi- cant. Meanwhile, if the ballistic testing were $p \geq 0.05$, it was not significant.

\section{Sample Characteristics}

Table 1 showed that the average age of 3-hour infusion group $(47.2+5.61)$ was the same as for 24 -hour infusion group $(47.3+5.88)$. The result is proved by 2 free samples of T-test which were found to be $p>0.05$, so it means that statistically, there was no significant difference in the mean age of patients.

The average of body area of 3-hour infusion group $(1.50 \pm 0.12)$ was the same as 24 -hour infusion group $(1.52 \pm 0.10)$. The result is proved by 2 free samples of T-test which were found to be $p>0.05$, so it means that statistically, there was no significant difference in the mean body area.

Table 1. Patients' general characteristics

\begin{tabular}{|c|c|c|c|c|c|}
\hline \multirow{2}{*}{$\begin{array}{c}\text { Characteristics } \\
\text { Age (Years) }\end{array}$} & \multicolumn{2}{|c|}{ 3-hour Infusion } & \multicolumn{2}{|c|}{ 24-hours Infusion } & \multirow{2}{*}{$\begin{array}{c}\text { Statistical } \\
\text { Testing }\end{array}$} \\
\hline & Frequency & $\%$ & Frequency & $\%$ & \\
\hline \multirow{3}{*}{$\begin{array}{l}30-40 \\
41-50 \\
51-60\end{array}$} & 0 & $0 \%$ & 0 & $0 \%$ & \multirow{4}{*}{$\begin{array}{c}\text { T-test } \\
\text { Pricing ratio } \\
p=0.96\end{array}$} \\
\hline & 8 & $80 \%$ & 6 & $60 \%$ & \\
\hline & 2 & $20 \%$ & 4 & $40 \%$ & \\
\hline Total Amount & 10 & $100 \%$ & 10 & $100 \%$ & \\
\hline \multicolumn{5}{|l|}{ Body Area } & \multirow{6}{*}{$\begin{array}{c}\text { T-test } \\
\text { Pricing ratio } \\
p=0.75\end{array}$} \\
\hline $1.30-1.40$ & 2 & $20 \%$ & 1 & $10 \%$ & \\
\hline $1.41-1.50$ & 3 & $30 \%$ & 2 & $20 \%$ & \\
\hline \multirow{2}{*}{$>1.61$} & 3 & $30 \%$ & 6 & $60 \%$ & \\
\hline & 2 & $20 \%$ & 1 & $10 \%$ & \\
\hline Total Amount & 10 & $100 \%$ & 10 & $100 \%$ & \\
\hline $\mathrm{Hb}$ & & & & & \multirow{6}{*}{$\begin{array}{c}\text { T-test } \\
\begin{array}{c}\text { Pricing ratio } \\
p=0.76\end{array}\end{array}$} \\
\hline $10.0-10.9$ & 2 & $20 \%$ & 2 & $20 \%$ & \\
\hline $11.0-11.9$ & 2 & $20 \%$ & 2 & $20 \%$ & \\
\hline $12.0-12.9$ & 3 & $30 \%$ & 3 & $30 \%$ & \\
\hline$\geq 13.0$ & 3 & $30 \%$ & 3 & $30 \%$ & \\
\hline Total Amount & 10 & $100 \%$ & 10 & $100 \%$ & \\
\hline \multicolumn{5}{|l|}{ Albumin } & \multirow{5}{*}{$\begin{array}{c}\text { T-test } \\
\text { Pricing ratio } \\
p=0.68\end{array}$} \\
\hline $2.75-3.49$ & 4 & $40 \%$ & 4 & $40 \%$ & \\
\hline $3.50-3.99$ & 4 & $40 \%$ & 5 & $50 \%$ & \\
\hline$\geq 4.00$ & 2 & $20 \%$ & 1 & $10 \%$ & \\
\hline Total Amount & 10 & $100 \%$ & 10 & $100 \%$ & \\
\hline
\end{tabular}


Furthermore, the average haemoglobin for 3-hour infusion group (11.9 \pm 1.1$)$ was the same as 24 -hour infusion group (12.1 \pm 1.2$)$. The result isproved by 2 free samples which were found to be $p>0.05$, so it means that there was no significant difference of haemoglobin.

Then, the average of albumin for 3-hour infusion group (3.5 \pm 0.4$)$ was the same as for 24 -hour infusion group (3.6 \pm 0.3$)$. The result of T-test free samples was obtained - pricing ration $p>0.05$, so it means that statistically, there were no significant difference of average albumin.

From the Table 2, it was obtained that in ovarian cancer stadium 3-hours infusion group there were IC (50\%) and IIIC (50\%). Meanwhile, in the 24-hour infusion group there were IC (60\%) and IIIC (40\%). Then, the result of Chi-square is obtained - pricing ratio $p=1.00(>0.05)$, so it means that there was no significant difference in clinical ovarian cancer.

The effort to get the right sample between the two groups was optimally obtained through statistical analysis. From 20 samples, it was seen that the two groups statistically showed no significant difference in age, body area, haemoglobin, albumin, as well as cancer clinical stadium. Hence, it could be said that the sample was homogeneous.

\section{Result Analysis}

\section{Chi-square test}

From Table 3, it was obtained that neutropenia condition in the 3-hour infusion group after chemotherapy was Paclitaxel-Carboplatin I (20 \%), Paclitaxel-Carboplatin II (30 \%), and Paclitaxel-Carboplatin III (30 \%). Meanwhile, in the 24-hour infusion group, the result of Chi-square test obtained that the pricing ration $p>005$, thus there was no significant difference in neutropenia condition of chemotherapy I, II, and III between 3-hour and 24-hour infusion.

Figure 1 figure showed the average amount of neutrophils which begin to decrease from chemotherapy I up to chemotherapy III. The decreasing is much bigger in the 24-hour infusion group rather than in the 3 -hour group. The result of T-test showed that in the 24-hour

Table 2. The characteristics of patients' stadium of ovarian cancer

\begin{tabular}{lcccccc}
\hline \multirow{2}{*}{ Stadium } & \multicolumn{2}{c}{ 3-hour infusion } & \multicolumn{2}{c}{ 24-hour infusion } & & \\
\cline { 2 - 7 } & Frequency & $\%$ & Frequency & $\%$ & Total & $\%$ \\
\hline I c & 5 & $50 \%$ & 6 & $60 \%$ & 11 & $55 \%$ \\
III c & 5 & $50 \%$ & 4 & $40 \%$ & 9 & $45 \%$ \\
\hline Total Amount & 10 & $100 \%$ & 10 & $100 \%$ & 20 & $100 \%$
\end{tabular}

Table 3. Neutropenia condition after chemotherapy

\begin{tabular}{lccccccc}
\hline \multirow{2}{*}{$\begin{array}{c}\text { Paclitaxel- } \\
\text { Carboplatin I }\end{array}$} & \multicolumn{2}{c}{ 3-hour infusion } & \multicolumn{2}{c}{ 24-hour infusion } & & & \multirow{2}{*}{ Pricing ratio p } \\
\cline { 2 - 6 } & Frequency & $\%$ & Frequency & $\%$ & Total & $\%$ & \\
\hline Neutropenia (+) & 2 & $20 \%$ & 4 & $40 \%$ & 6 & $30 \%$ & $\mathrm{p}=0.62$ \\
\cline { 2 - 7 } Neutropenia (-) & 8 & $80 \%$ & 6 & $60 \%$ & 14 & $70 \%$ & \\
\hline Total & 10 & $100 \%$ & 10 & $100 \%$ & 20 & $100 \%$ & \\
\hline Paclitaxel-Carboplatin II & & & & & & \\
\hline Neutropenia (+) & 3 & $30 \%$ & 5 & $50 \%$ & 8 & $40 \%$ & $\mathrm{p}=0.65$ \\
Neutropenia (-) & 7 & $70 \%$ & 5 & $50 \%$ & 12 & $60 \%$ & \\
\hline Total & 10 & $100 \%$ & 10 & $100 \%$ & 20 & $100 \%$ & \\
\hline Paclitaxel-Carboplatin III & & & & & & \\
\hline Neutropenia (+) & 3 & $30 \%$ & 4 & $40 \%$ & 7 & $35 \%$ & $\mathrm{p}=1.00$ \\
Neutropenia (-) & 7 & $70 \%$ & 6 & $60 \%$ & 13 & $65 \%$ & \\
\hline Total & 10 & $100 \%$ & 10 & $100 \%$ & 20 & $100 \%$ & \\
\hline
\end{tabular}


Average Amount of Neutrophils $\left(\right.$ cell $\left./ \mathrm{mm}^{3}\right)$

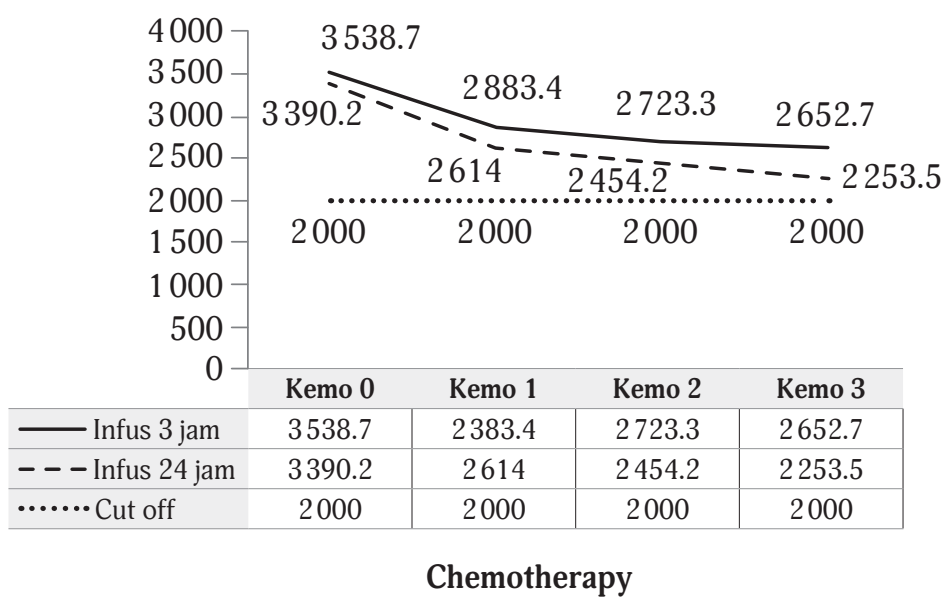

Fig. 1. The differences of decreasing amount of neutrophils

infusion, the decrease of neutrophils before and after chemotherapy I obtained significant result ( $p<0.0001)$, after chemotherapy II it also obtained significant result $(p=0.03)$, however, after chemotherapy III the result was insignificant $(p=0.11)$.

Meanwhile, in the 3-hour infusion group T-test result showed a decrease in neutrophils before and after chemotherapy I - significant result $(p<0.0001)$. But after chemotherapy II, there were no significant results $(p=$ 0.281 ), and after chemotherapy III also there were no significant results $(p=0.252)$.

\section{T-test}

In the Table 4, concerning 3-hour infusion, it was obtained that before chemotherapy and after chemotherapy I, the amount of neutrophil was decreasing up to $19 \%$. After chemotherapy II, the result compared to chemotherapy I showed decreasing up to $5.9 \%$ and after chemotherapy III - decreasing up to $1.2 \%$. On the other hand, in the 24 hour infusion group, before and after chemotherapy I the amount of neutrophils decreased to $23.8 \%$, after chemotherapy II $-7.5 \%$, and after chemotherapy III $-8.6 \%$. In the T-test, the comparison between the amounts of neutrophils in the 3-hour infusion group and 24-hour infusion group, there was no significant difference with the amount $\mathrm{p}>0.05$ whether after chemotherapy I, II, or III.

\section{Chi-square test}

Table 5 shows neuropathy condition in the 3-hour infusion group after chemotherapy Paclitaxel-Carboplatin I (30\%), Paclitaxel-Carboplatin II (60\%), and Paclitaxel-Carboplatin III (50\%). Meanwhile, in the 24-hour-infusion group, neuropathy condition after Paclitaxel-Carboplatin I was $20 \%$, after Paclitaxel-Carboplatin II - 20\%, and after Paclitaxel-Carboplatin III - 20\%. Then, the result of Chisquare test obtained pricing ratio $p>0.05$, so there was no significant neuropathy condition in the chemotherapy I, II, and III in the 3-hour and 24-hour infusion group.

Figure 2 showed that the average amplitude wave is continuously decreasing. The decreasing in the 3-hour infusion group is more significant than in the 24-hour infusion group. The T-test showed that the decreasing of amplitude wave was significantly clear after and before chemotherapy I ( $p=0.009)$, as well as after chemotherapy III and II ( $p=0.007)$. While, in the 24-hour infusion group, the decreasing of amplitude wave was clearly significant after and before chemotherapy I ( $<<0.0001)$, after chemotherapy II and chemotherapy I $(p=0.04)$, and after chemotherapy III and chemotherapy II $(p=0.15)$.

\section{T-test}

Table 6 shows the decreasing of amplitude wave about $16.8 \%$ in the 3 -hour infusion group after and before

Table 4. Percentage of decreasing amount of neutrophils in each chemotherapy

\begin{tabular}{lccc}
\hline & Chemotherapy I-0 & Chemotherapy II-I & \multicolumn{2}{c}{ Chemotherapy III-II } \\
\hline 3 hours & $19.0 \%$ & $5.9 \%$ & $1.2 \%$ \\
\hline 24 hours & $23.8 \%$ & $7.5 \%$ & $8.6 \%$ \\
\hline Pricing ratio p & 0.37 & 0.77 & 0.24 \\
\hline
\end{tabular}


Table 5. Neuropathy condition after chemotherapy

\begin{tabular}{|c|c|c|c|c|c|c|c|}
\hline \multirow{2}{*}{$\begin{array}{l}\text { Paclitaxel- } \\
\text { Carboplatin I }\end{array}$} & \multicolumn{2}{|c|}{ 3-hour infusion } & \multicolumn{2}{|c|}{ 24-hour infusion } & \multirow[b]{2}{*}{ Total } & \multirow[b]{2}{*}{$\%$} & \multirow{2}{*}{ Pricing ratio $p$} \\
\hline & Frequency & $\%$ & Frequency & $\%$ & & & \\
\hline \multirow{2}{*}{$\begin{array}{l}\text { Neuropathy (+) } \\
\text { Neuropathy (-) }\end{array}$} & 3 & $30 \%$ & 2 & $20 \%$ & 5 & $25 \%$ & \multirow{3}{*}{$\mathrm{p}=1.00$} \\
\hline & 7 & $70 \%$ & 8 & $80 \%$ & 15 & $75 \%$ & \\
\hline Total & 10 & $100 \%$ & 10 & $100 \%$ & 20 & $100 \%$ & \\
\hline \multicolumn{8}{|c|}{ Paclitaxel-Carboplatin II } \\
\hline \multirow{2}{*}{$\begin{array}{l}\text { Neuropathy (+) } \\
\text { Neuropathy (-) }\end{array}$} & 6 & $60 \%$ & 2 & $20 \%$ & 8 & $40 \%$ & \multirow{3}{*}{$p=0.17$} \\
\hline & 4 & $40 \%$ & 8 & $80 \%$ & 12 & $60 \%$ & \\
\hline Total & 10 & $100 \%$ & 10 & $100 \%$ & 20 & $100 \%$ & \\
\hline \multicolumn{8}{|c|}{ Paclitaxel-Carboplatin III } \\
\hline \multirow{2}{*}{$\begin{array}{l}\text { Neuropathy (+) } \\
\text { Neuropathy (-) }\end{array}$} & 5 & $50 \%$ & 2 & $20 \%$ & 6 & $30 \%$ & \multirow{3}{*}{$\mathrm{P}=0.35$} \\
\hline & 5 & $50 \%$ & 8 & $80 \%$ & 14 & $70 \%$ & \\
\hline Total & 10 & $100 \%$ & 10 & $100 \%$ & 20 & $100 \%$ & \\
\hline
\end{tabular}

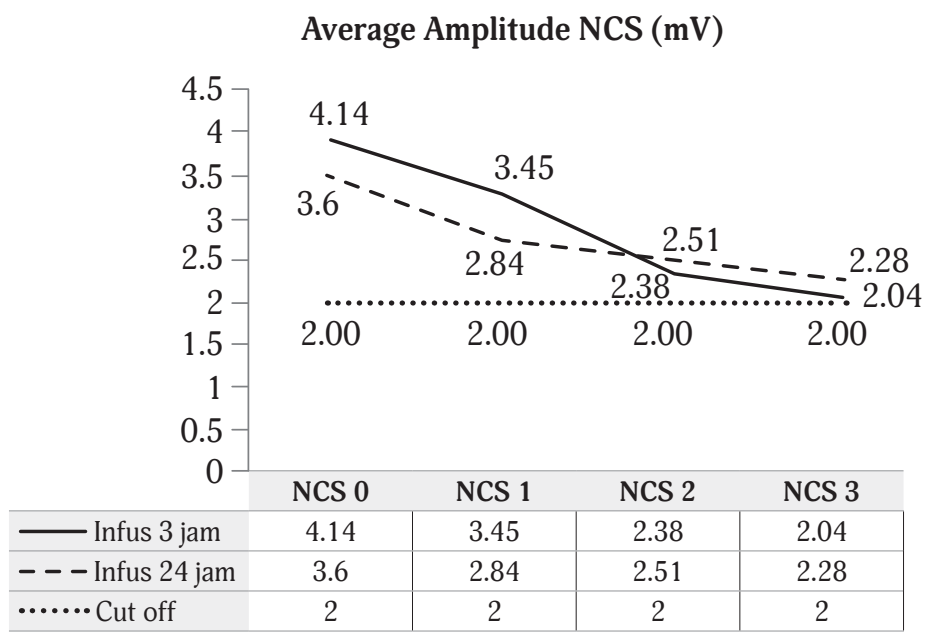

\section{Chemotherapy}

Fig. 2. Difference of decreasing amplitude wave

Table 6. Percentage of the decreasing of amplitude wave after chemotherapy

\begin{tabular}{lccc}
\hline & $\begin{array}{c}\text { Chemo- } \\
\text { therapy I-0 }\end{array}$ & $\begin{array}{c}\text { Chemo- } \\
\text { therapy II-I }\end{array}$ & $\begin{array}{c}\text { Chemo- } \\
\text { therapy III-II }\end{array}$ \\
\hline 3 hours & $16.8 \%$ & $29.1 \%$ & $21.0 \%$ \\
\hline 24 hours & $20.8 \%$ & $12.3 \%$ & $9.3 \%$ \\
\hline $\begin{array}{l}\text { Pricing } \\
\text { ratio p }\end{array}$ & 0.64 & 0.11 & 0.17 \\
\hline
\end{tabular}

chemotherapy I, after chemotherapy II $-29.1 \%$ if compared to chemotherapy I, and after chemotherapy III $21.0 \%$. In the 24 -hour infusion group, before and after chemotherapy I, the decreasing amount of neutrophils was about $20.8 \%$, after chemotherapy II $-12.3 \%$ if compared to chemotherapy I, and after chemotherapy III- $9.3 \%$. The T-test showed no significant difference in $p>0.05$ whether after chemotherapy I, II, or III. 


\section{Discussion}

The combination of taxane wave (Paclitaxel-Docetaxel) with the platinum-based wave (Cisplatin-Carboplatin) is a kind of chemotherapy regiment for ovarian cancer in which there are hot issues to discuss and research to obtain since it become the primary choose in the chemotherapy medicine.

Hence, this study is obtained to scrutinize the difference between side effects - neutropenia and neuropathy after chemotherapy Paclitaxel-Carboplatin given in 3 and 24 hours of infusion to ovarian cancer patients, in which the surgical staging was optimally performed since December 2008 up to May 2009.

The side effect that most often occurs in Paclitaxel-Carboplatin is hypersensitive reaction. Grant and Kris reported in the study the phase I - there was obtained a hypersensitive reaction about $30-40 \%$ during 3-hour infusion. The risk will be increasing if Paclitaxel-Carboplatin is given in short time. In the implementation, the pre-medication with the help of corticosteroid was helping to reduce this kind of reaction, thus, in the further study, on phase II, phase III, and phase IV, hypersensitive condition will rarely happen [17].

In this study, researchers have found that $2 \mathrm{pa}-$ tients from 3-hour infusion group and 1 patient from 24-hour infusion group were experiencing hypersensitiveness. The symptoms can be in the form of urticarial itch but not shock. However, the implementation of infusion should be rapid and precise so that patients will not get into shock condition. It can be performed by controlling airways, breathing, and circulation which include evaluation of airways, giving oxygen mask, and live saving infusion.

\section{Sample characteristics}

Total of samples involved into this study were $20 \mathrm{pa}-$ tients with ovarian cancer and obtained optimum surgical staging and adjuvant Paclitaxel-Carboplatin chemotherapy. The average age of patients in the 3-hour infusion group $-47.2+5.61$, the average age of patients in the 24 -hour infusion group $-47.3 \pm 5.88$. This result was proved by the T-test of 2 free samples which obtained pricing ratio $p>0.05$. It means that statistically, there were no significant differences in patients' age. Furthermore, the average of body area in 3-hour infusion group was the same $(1.50 \pm 0.12)$ compared to 24 -hour infusion group $(1.52 \pm 0.10)$. The T-test of free samples obtained the pricing ratio $p>0.05$. It means that statistically, there were no significant differences in body area. The result of Chi-square test of ovarian cancer stadium on both of groups found that the pricing ratio $p=1.00(>0.05)$, so it means there were no significant differences.

\section{Basic Variable Election}

Researchers observed patients with ovarian cancer in dr. Soetomo Public Health Hospital, where they performed chemotherapy and suddenly become deteriorate, feeling unwell and weak, thus leading to sepsis condition. Afterward, the further observation was done and thus it was concluded that patients were getting neutropenia febrile the condition that can cause death. Hence, researchers assumed that neutrophil was the first defence mechanism to the infection where neutrophil was the biggest part of leukocyte - about 50-60\%. Neutropenia then considered as the most frequent side effect in chemotherapy using Paclitaxel and Carboplatin.

The side effect of non-haematology which caused pain from cancer metastases was peripheral neuropathy. From several literatures, it was mentioned that medical treatment by neutrophil groups did not provide therapy improvement and the effect of neutrophil will lead to the progress of cancer (resistant). Nowadays, the degree of peripheral neuropathy based on WHO and ECOG merely depends on the subjective lamentation, yet no agreement toward objective treatment as gold treatment standard. From the previous studies, NCS (Nerve Condition Study) was an objective observation tool often used due to its sensitivity and good specification to know the first symptom from peripheral neuropathy condition.

\section{Result Analysis}

In the general characteristics of 20 samples, both of the groups did not show signs and symptoms of neutropenia and peripheral neuropathy before the chemotherapy. Statistically, there were no significant differences in age, body area, and clinical stadium of patients while given Paclitaxel-Carboplatin in the 3- and 24-hour infusion groups. Meanwhile, Kolmogorov-Smirnov Z test found the value $p>0.05$ which means that all of the samples were homogeneous, and did not affect the further comparison.

\section{Comparison of Neutropenia between the two Groups in Paclitaxel-Carboplatin Chemotherapy}

Neutropenia is described as side effect of chemotherapy that by age, balance or imbalance nutrition, kidney and liver disease, experience of chemotherapy/radiation in previous, infection factors, post-surgery/wounds opens by the invasion of cancer cell. The degree of neutropenia depended on the result of absolute neutrophil count (ANC) under $2000 \mathrm{cell} / \mathrm{mm}^{3}$. ANC then depicted as the amount of leucocytes and polimorphonuclear cell fraction (PMN) and band form according to the pattern below:

$$
\begin{aligned}
& \text { ANC = leucocyte cell }\left(\text { cell } / \mathrm{mm}^{3}\right) \times \\
& \text { percentage }(\mathrm{PMNs}+\text { bands }): 100
\end{aligned}
$$


In this study, it was found that neutropenia in 24hour infusion group was $50 \%$, while in the 3 -hour group infusion $-30 \%$. From the 24-hour infusion group, there were 2 patients of neutropenia degree 1, 2 patients of neutropenia degree 2 with the amount of leucocytes $<4,0 \times 10^{3} / \mu \mathrm{L}$ and the amount of neutrophils - no more than $1500 \mathrm{cell} / \mathrm{mm}^{3}$, also a patient degree 3 in which the amount of leucocytes was $<4,0 \times 10^{3} / \mu \mathrm{L}$ and the amount of neutrophils - less than 1000 that necessary to get G-CSF injection therapy. Afterward, in the 3-hour infusion group, it was obtained that 3 patients of neutropenia degree 1 did not need to get G-CSF therapy. Thus, there was no significant difference after chemotherapy I, II, and III from both of the groups with statistical value $\mathrm{p}>0.05$.

The decrease of the amount of neutrophils was higher in the 24-hour infusion group than in the 3-hour infusion group. The T-test in the 24-hour infusion group showed that the decreasing of neutrophils before and after chemotherapy I obtained the significant result ( $p$ $<0.0001$ ), after chemotherapy II and I it also obtained the significant result $(p=0.03)$, however after chemotherapy III, the result was insignificant $(p=0.11)$. In the 3 -hour infusion group, the decreasing of the amount of neutrophils before and after chemotherapy I obtained the significant result $(p<0.0001)$, but unfortunately, after chemotherapy II the result was insignificant ( $p=$ 0.281 ), and after chemotherapy III, the result remained insignificant $(p=0.252)$. Thus, it strengthens the theory which mentioned that the highest decrease of the amount of neutrophils was after the implementation of chemotherapy I, since there was an organ and tissues cell shock condition, thus it would lead to adaptation by increasing the production of progenitor cell/stem cell after several chemotherapies.

The neutropenia condition of 3-hour infusion group happened for patients of old age and in the state of high stadium (IIIC). Meanwhile, in the 24-hour infusion group, the difference incidence was obtained, in which the neutropenia condition occured in the former stadium. Therefore, it can be concluded that neutropenia condition in the 3 -hour infusion group was not merely influence by the time dependent factor and dosage, but it also depends on other extrinsic factors such as interval between further chemotherapy, haemoglobin, lipid/albumin profile. Furthermore, it also assumed that it was influenced by intrinsic factors such as progression of cancer cell of further stadium to the bone marrow which can affect bonding/ communication between cells compared to the 24-hour group infusion $[18,19,20]$.

The results of this study were the same as Kris' (1995) for breast cancer (paclitaxel dosage $190 \mathrm{mg} / \mathrm{m}^{2}$ ), Schiller' and Sarosy' for ovarian cancer further stadium (Paclitaxel dosage $210 \mathrm{mg} / \mathrm{m}^{2}$ dan $250 \mathrm{mg} / \mathrm{m}^{2}+\mathrm{G}$-CFS) stated that in the 24-hour infusion group, there was no significant difference in neutropenia compared to the 3-hour infusion group.

Meanwhile, the difference showed by Rowinsky and Donehower in which the amount of neutropenia condition was bigger in the group $1-6$ hours. Ohtsu (1995) added that the dosage for 3 hours was $210 \mathrm{mg} / \mathrm{m}^{2}$ and for 24 hours $-135 \mathrm{mg} / \mathrm{m}^{2}$, then the amount of neutropenia in the 3-hour infusion group was less than those for 24hour infusion group ( $40.7 \%$ versus $66.7 \%$ ). Wiernik et al. stated that the dosage should be paclitaxel $250 \mathrm{mg} / \mathrm{m}^{2}$, and Ohnuma added that the dosage $200 \mathrm{mg} / \mathrm{m}^{2}$ would increase the side effect of neutropenia, since the neutropenia was dosage dependent, time dependent, and Paclitaxel-carboplatin infusion. Jennens used each of dosage $175 \mathrm{mg} / \mathrm{m}^{2}$ and obtained that there was no significant difference between 3- and 6-hour infusions, but it obtained an increase in the neutropenia in the 24-hour infusion group. Peretz stated that significant difference between neutropenia in the 3- and 24-hour infusion groups were $30 \%$ and $60 \%$ using paclitaxel $175 \mathrm{mg} / \mathrm{m}^{2}(\mathrm{n}=521)[13$, 14, 18, 19, 20, 21].

Table 3 showed that neutropenia condition mostly oc-curs after the first treatment with PaclitaxelCarboplatin and it starts to stabilize in the second and third chemo-therapy. It caused by the adaptation in the stem cell. There was no significant difference between the 3- and 24-hour infusion groups after chemotherapy I (20\% ver-sus $40 \%$ ). Furthermore, acute granulocytopenia occurs 6-12 days after the chemotherapy, and the recovery oc-curs in 10-14 days. Thus, it can be used as consideration that the right time to obtain further chemotherapy \pm 21 days. Besides the amount of dosage given, the duration of chemotherapy infusion and clinical stadium, other factors which influence neutropenia condition is the age factor and malnutrition.

Figure 5 and Table 4 showed that administration of Paclitaxel-Carboplatin during 24-hour infusion can cause decrease of the amount of neutrophils higher than those during 3-hour infusion. Theoretically, this was caused by the duration of chemotherapy medicine concentration in the plasma in steady state which is above the physiological threshold value (Vss $\uparrow$ and MRT $\uparrow$ ) giving longer time for blood flow to carry active drug substances from the central compartment to the tissues' compartment. Then it penetrates into the body's tissue, especially the bone marrow and influencing the stages of hematopoietic/hemocytoblast cell division and maturation due to the mitotic spindle transport that will lead to maturation defect and the reduced amount of neutrophils $[8,13,14]$. 


\section{Comparison of Peripheral Neuropathy between the two Groups in Paclitaxel-Carbopla- tin Chemotherapy}

In this study, the side effects of peripheral neuropathy in the 24 -hour infusion group were $30 \%$. Meanwhile, in the 3-hour infusion group - $60 \%$ with the statistical test $p>0.05$. Therefore it can be concluded that there were no significant difference. In the table 5 , a clear difference was obtained in which the peripheral neuropathy in the 3 -hour infusion group occurred after the administration of Paclitaxel-Carboplatin II (60\%). Meanwhile in the 24hour infusion group, there was no difference either after the first, second, or even third chemotherapy (20\%).

In the 3-hour infusion group, the tendency of neuropathy to be apparent after the second chemotherapy in which it obtained the significant result $(p=0.031)$, while in the 24-hour infusion group, the tendency of neuropathy was not significantly different before and after first chemotherapy $(p=0.500)$, second chemotherapy $(p=$ $0.500)$, and third chemotherapy $(p=0.500)$. However, it was strengthen by the NCS observation which was apparent in the decreasing of amplitude wave in the 3-hour infusion group compared to 24 -hour infusion group. The T-test showed the decrease in amplitude wave in the 3 -hour infusion group significant either after the first chemotherapy and before the second chemotherapy $(\mathrm{p}=$ $0.05)$, after second chemotherapy with the first chemotherapy ( $p=0.009)$, and after the third chemotherapy with the second chemotherapy $(p=0.007)$. Meanwhile, in the 24-hour infusion group, the decrease of amplitude wave was significantly clear after the first chemotherapy before second chemotherapy $(p<0.0001)$, after second chemotherapy with the first chemotherapy $(p=0.04)$, it does not occur after the third chemotherapy with the second chemotherapy $(p=0.15)$.

In this study, researchers found that a patient from 3 -hour infusion group had neuropathy degree increasing, either from subjective lamentation or NCS observation (degree 2-3) after the second series chemotherapy, hence, researchers tried to reduce paclitaxel dosage which was about $20 \%$. A patient from 3-hour infusion group after the first chemotherapy had tingling lamentation and the NCS result showed that there was neuropathy in $n$. suralis, but after further chemotherapy the condition was reversible. Then, it concluded that the patient had light neuropathy lamentation in which $n$. suralis just merely hadfunction as sensory. Most of patients from 3-hour infusion group or 24-hour infusion group from the NCS observation had peripheral neuropathy in n. peroneus compared with $n$. tibialis. In this case, it was possible since the $n$. peroneus diameter was tinier than $n$. tibialis, so that the amount of nerve fibres was also less and if the number of nerve fibres were the same between $n$. tibialis and $n$. peroneus. Hence, $n$. peroneus was not reversible [22].

This result was similar with the research obtained by Smith in National Surgical Adjuvant Breast and Bowel Project B-26 toward breast cancer patients, peripheral neuropathy grade $3-4$ which occured in $22 \%$ of patients and included into 3-hour Paclitaxel infusion group (250 mg/m²; $\mathrm{n}=279$ ) and $13 \%$ of patients included into 24-hour Paclitaxel infusion group $\left(250 \mathrm{mg} / \mathrm{m}^{2} ; \mathrm{n}=284\right)$. In a paclitaxel randomization phase III $\left(135\right.$ or $\left.175 \mathrm{mg} / \mathrm{m}^{2}\right)$ in ovarian carcinoma, there was no significant difference in the peripheral neuropathy condition grade $3-4$ which is about $0.7 \%$ in the 3 -hour infusion group $(\mathrm{n}=187)$ and $0.6 \%$ in 24 -hour infusion group $(\mathrm{n}=204)$. Peretz stated that patients with breast cancer had compared paclitaxel $175 \mathrm{mg} / \mathrm{m}^{2}(\mathrm{n}=521)$ between 3- and 24-hour infusion groups found that peripheral neuropathy was $78 \%$ versus $65 \%$ (insignificant) [21].

According to Rowinsky and Donehower, the side effect of peripheral neuropathy was tending to the usage of dosage. They proved that in recurrent ovarian cancer patients with paclitaxel dosage between $135 \mathrm{mg} / \mathrm{m}^{2}$ up to $250 \mathrm{mg} / \mathrm{m}^{2}$ in the 3-hour infusion group if compared to 24-hour infusion group, there were no significant difference. But, with the dosage $>250 \mathrm{mg} / \mathrm{m}^{2}$, then peripheral neuropathy will appear and not be influenced by the infusion duration [18].

However, the difference result showed by Ohtsu (1995) with the 3 -hour dosage infusion is about $210 \mathrm{mg} / \mathrm{m}^{2} ; \mathrm{n}=$ 27 and the 24 -hour infusion were $135 \mathrm{mg} / \mathrm{m}^{2} ; \mathrm{n}=15$. The number of peripheral neuropathies in the 3 -hour infusion group was bigger than for 24-hour infusion group (63\% versus $6.4 \%$ ) [13].

According to McPhee, the factors that influence the emergence of side effects in peripheral neuropathy were the magnitude of dosage, age, nutritional status, diabetes mellitus, long-term consumption of alcohol and the interval time between chemotherapy and surgical staging surgery [22].

In Figure 2 and Table 6, the administration of 3-hour Paclitaxel-Carboplatin infusion tends to have greater peripheral neuropathy as evidenced by a decrease in the amplitude wave $n$. peroneus compared to 24-hour infusion. Theoretically, the incidence of peripheral neuropathy has increased during 3-hour infusion due to the presumption that maximal concentration $\left(\mathrm{C}_{\max }\right)$ was achieved in a short time $\left(\mathrm{t}_{\max }\right)$ accompanied by higher dosages as the main determinant. However, it was found only in the central compartment but not in the tissue compartment causing distribution (MRT), and elimination would become saturated in proportion to the length of exposure, and drug dosage would inhibit body neuron cells and Schwann cells that have excellent blood vessel cyclic velocity and the cell cycle is rapid, $\mathrm{G}_{2} / \mathrm{M}$ phase lasts $3-4$ hours thus caus- 
ing inhibition of cell proliferation and regeneration does not work well [11].

\section{Conclusion}

Based on the result of the research, it can be concluded that there was no significant increase in neutropenia in the 24-hour Paclitaxel infusion group compared to the 3-hour infusion group in Paclitaxel-Carboplatin adjuvant therapy. Afterward, it did not obtain the significant increase toward peripheral neuropathy in the 3-hour Paclitaxel infusion group compared to 24-hour infusion group in adjuvant Paclitaxel-Carboplatin therapy.

\section{References}

1. Benedet JL, Hacker NF, Ngan HYS. Staging classification and clinical practice guidelines of gynaecologic cancers: FIGO Committee on Gynecologic Oncology and IGCS Guidelines. Sec ed. Elsevier; 2003. p. 92-114.

2. Stirrat GM, Mills MS, Draycott TJ. Ovarian neoplasma: Obstetrics and Gynaecology. British. Churchill Livingstone; 2003. p. 308-317.

3. Aziz MF, Andrijono, Saifuddin AB. Buku Acuan Nasional Onkologi Ginekologi. Jakarta : Yayasan Bina Pustaka Sarwono Prawirohardjo; 2006.

4. Berek JS. Ovarian cancer: Novak's Gynecology. Ch 32. Ed. Berek JS. Lippincott Williams and Wilkins; 2002.

5. Angioli R, Panici PB, Kavanagh JJ, Pecorelli S, et al. Chemotherapy for Gynecological neoplasms. New York: Maecel Dekker; 2004. p. 1 - 32.

6. Bristow RE, Karlan BY. Surgery for Ovarian Cancer. Oxon, U.K; 2006. p. 87 - 171.

7. Fraser M, Leung B, Thompson WE, Tsang B, et al. Chemoresistance in human ovarian cancer: the role of apoptotic regulators. Reproductive biology and endocrinology 1: $66-79 ; 2003$.

8. Chabner BA, Longo L. Cancer Chemotherapy and Biotherapy, Principles and Practice 4th ed. Philadelphia. Lippincott Williams and Wilkins. 2006.

9. Breathnach OS, Kasturi V, Kaye F, Herscher L, Georgiadis MS, Edison M, et al. Phase II Neoadjuvant Trial of Paclitaxel by 96 -Hour Continuous Infusion (CIVI) in Combination With Cisplatin Followed by Chest Radiotherapy for Patients With Stage III Non-Small-Cell Lung Cancer. American Journal of Clinical Oncology [Internet]. Ovid Technologies (Wolters Kluwer Health); 2002 Jun;25(3):269-73. Available from: https://doi.org/10.1097/00000421-200206000-00013

10. Du Bois A. A Randomized Clinical Trial of Cisplatin/Paclitaxel Versus Carboplatin/Paclitaxel as First-Line Treatment of Ovarian Cancer. CancerSpectrum Knowledge Environment [Internet]. Oxford University Press (OUP); 2003 Sep 3;95(17):1320-9. Available from: https://doi. org/10.1093/jnci/djg036

11. Brighton D, Wood Miriam. The Royal Marsden Hospital Handbook of Cancer Chemotherapy. British. Elsevier Churchill Livingstone; 2005. p. 3-30.

12. Moore KN, Herzog TJ, Lewin S, Giuntoli RL, Armstrong DK, Rocconi RP, et al. A comparison of cisplatin/paclitaxel and carboplatin/paclitaxel in stage IVB, recurrent or persistent cervical cancer. Gynecologic Oncology [Internet]. Elsevier BV; 2007 May;105(2):299-303. Available from: https:// doi.org/10.1016/j.ygyno.2006.12.031

13. Ohtsu T, Sasaki Y, Tamura T, Miyata Y, Nakanomyo H, Nishiwaki Y, et al. Clinical pharmacokinetics and pharmacodynamics of paclitaxel: a 3-hour infusion versus a 24-hour infusion. Clin Cancer Res. 1995 Jun;1(6):599-606.

14. Jennens R, Rischin D, Yuen K, Toner G, Millward M. Comparison of neutropenia in a randomized, crossover trial of 3-, 6-, and 24-h infusions of paclitaxel. Gynecologic Oncology [Internet]. Elsevier BV; 2003 Oct;91(1):190-3. Available from: https://doi.org/10.1016/s0090-8258(03)00459-1

15. Mielke S. Association of Paclitaxel Pharmacokinetics with the Development of Peripheral Neuropathy in Patients with Advanced Cancer. Clinical Cancer Research [Internet]. American Association for Cancer Research (AACR); 2005 Jul 1;11(13):4843-50. Available from: https://doi. org/10.1158/1078-0432.ccr-05-0298

16. Lee JJ, Swain SM. Peripheral Neuropathy Induced by Microtubule-Stabilizing Agents. Journal of Clinical Oncology [Internet]. American Society of Clinical Oncology (ASCO); 2006 Apr;24(10):1633-42. Available from: https://doi. org/10.1200/jco.2005.04.0543

17. Grant SC, Kris MG. New antineoplastic agents in lung cancer 1988-1993. Lung Cancer [Internet]. Springer US; 1994;323-47. Available from: https://doi. org/10.1007/978-1-4615-2630-8_15

18. Rowinsky EK, Donehower RC. Paclitaxel (Taxol). Wood AJJ, editor. New England Journal of Medicine [Internet]. Massachusetts Medical Society; 1995 Apr 13;332 (15):1004-14. Available from: https://doi.org/10.1056/ nejm199504133321507

19. Bagby GC. Leukopenia and leukocytosis. Cecil Textbook of Medicine 22nd edition. Goldman L, Ausiello D eds. Saunders, Philadelphia; 2007. 90-98.

20. Ashariati A. Komplikasi neoplasia dan terapi. Naskah lengkap Surabaya Hematologi Onkologi Medik Update-IV. Editor Boediwarsono, Sugianto, Ashariati A, Sedana MP, Ugroseno. Surabaya September 2nd. 2006; 59-67.

21. Wiernik PH, Yeap B, Vogl SE, Kaplan BH, Comis RL, Falkson $\mathrm{G}$, et al. Hexamethylmelamine and Low or Moderate Dose Cisplatin With or Without Pyridoxine for Treatment of Advanced Ovarian Carcinoma: A Study of the Eastern Cooperative Oncology Group. Cancer Investigation [Internet]. Informa UK Limited; 1992 Jan;10(1):1-9. Available from: https://doi.org/10.3109/07357909209032783

22. Ohnuma H, Sato Y, Hayasaka N, Matsuno T, Fujita C, Sato M, Osuga T, Hirakawa M, Miyanishi K, Sagawa T, Fujikawa K, Ohi M, Okagawa Y, Tsuji Y, Hirayama M, Ito T, Nobuoka T, Takemasa I, Kobune M, Kato J. Neoadjuvant chemotherapy with docetaxel, nedaplatin, and fluorouracil for resectable esophageal cancer: A phase II study. Cancer Sci. 2018; 109(11):3554-3563.

23. Ohnuma H, Sato Y, Hayasaka N, Matsuno T, Fujita C, Sato M, et al. Neoadjuvant chemotherapy with docetaxel, nedaplatin, and fluorouracil for resectable esophageal cancer: A phase II study. Cancer Science [Internet]. Wiley; 2018 Sep 25;109(11):3554-63. Available from: https://doi. org/10.1111/cas.13772 
24. Peretz T, Sulkes A, Chollet P, Gelmon K, Paridaens R, Gorbonuva V, et al. 345 A multicenter, randomized study of two schedules of paclitaxel (PTX) in patients with advanced breast cancer (ABC). European Journal of Cancer [Internet]. Elsevier BV; 1995 Nov;31:S75. Available from: https://doi.org/10.1016/0959-8049(95)95598-Z

Порівняння нейтропенії та периферичної нейропатії після 3-годинної та 24-годинної інфузії Паклітакселу в складі хіміотерапії Паклітаксел-Карбоплатином у пацієнтіок із раком яєчників

Primandono Perbowo, Brahmana Askandar, Sunjoto, Ratna D Soebadi, Ahcmad Bashori

Відділ гінекологічної онкології, відділення акушерства та гінекології Університету Айрлангга, Державна лікарня імені Соетомо, м. Сурабая, Індонезія

Резюме. Метою дослідження було порівняти різниияю у нейтропенії та стані периферичної нейропатії після призначення 3-годинної та 24-годинної інфузії Паклітакселу в складі ад’ювантної хіміотерапії Паклітаксела-Карбоплатином у пациієнтів із карцциномою яєчників. Були використані методи експериментального дослідження із включенням пацієнтів після перевірки критеріїв включення. Рівні нейтрофілів та диференціійна лабораторна панель перевірялись до і після кожної хіміотерапії з наступною статистичною оцінкою Т-критерію та критерію Пірсона. Результати показали, щзо після триразового 3-годинного введення Паклітакселу-Карбоплатину стан нейтропенії від першого до третього введення спостерігався у 20\%; 30\%; 30\% і периферичної нейропатії - у 30\%; 60\%; $50 \%$ відповідно. У той же час при 24-годинній інфузії частота нейтропенії складала 40\%; 50\%; 40\% і частота периферичної нейропатії - 20\%; 20\%; 20\% відповідно. Статистична достовірність склала $p>0,05$. Не було виявлено значної різниці у частоті нейтропенії та периферичної нейропатії у двох досліджуваних груnax.

Ключові слова: нейтропенія, периферична нейропатія, Паклітаксел, Карбоплатин, карциинома яєчників, дослідження нервового проведення.
25. Preston DC, Shapiro BE. Electromyography and Neuromuscular Disorders: Clinical-Electrophysiologic Correlations.2nd ed. Elsevier. Philadelphia, 2005. 25-37.

Сравнение нейтропении и периферической нейропатии вследствие 3-часовой и 24-часовой инфузии Паклитаксела в составе Паклитаксел-Карбоплатиновой химиотерапии у пациенток с раком яичников

Primandono Perbowo, Brahmana Askandar, Sunjoto, Ratna D Soebadi, Ahcmad Bashori

Отдел гинекологической онкологии, отделение акушерства и гинекологии Университета Айрлангга, Государственная больнициа имени Соетомо., г. Сурабая, Индонезия

Резюме. Целью исследования было сравнить разнииу в нейтропении с состоянием периферической нейропатии после назначения 3-часовой и 24-часовой инфузии Паклитаксела в составе адъювантной химиотерапии Паклитаксела-Карбоплатина у пацииентов с каризиномой яичников. Были использованы методы экспериментального исследования с включением пациентов после проверки критериев включения. До и после каждой химиотерапии определялись уровни нейтрофилов и дифференциальная лабораторная панель с последующей статистической оценкой Т-критерия и критерия Пирсона. Результаты показали, что после трехкратного 3-часового введения Паклитаксела-Карбоплатина состояние нейтропении от первого к третьему введению составляло 20\%; 30\%; 30\% и периферической нейропатии - 30\%; 60\%; 50\% соответственно. В то же время при 24-часовой инфузии частота нейтропении составляла 40\%; $50 \%$; $40 \%$ и частота периферической нейропатии - 20\%; 20\%; $20 \%$ соответственно. Статистическая достоверность составила $p>0,05$. Не было обнаружено значительной разницы в частоте нейтропении и периферической нейропатии в двух иследовательских группах.

Ключевые слова: нейтропения, периферическая нейропатия, Паклитаксел, Карбоплатин, карциинома яичников, исследования нервного проведения. 